editorial / JULIA GATLEY

\title{
From Beaux-Arts to BIM
}

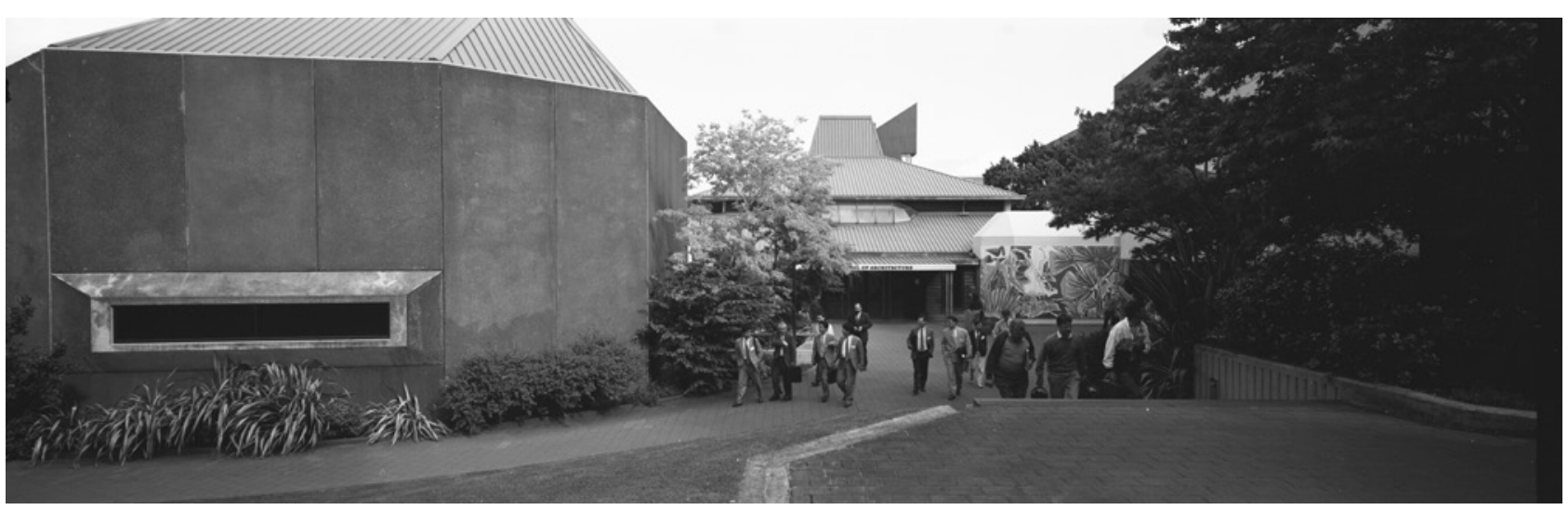

Fig. 1 The entry to the Auckland School of Architecture in 1991. [University of Auckland Libraries and Learning Services, Record Number 557368]
In September 2017, the University of Auckland's School of Architecture and Planning celebrated its centenary. We launched a book on the School's history (Gatley \& Treep 2017), and opened an extensive exhibition of drawings, photographs, models, and ephemera, also from the School's first 100 years (Milojevic, Treep, Barrie, \& Gatley 2017). There were three further exhibitions: current student work (Manfredini \& Rieger 2017); library and archive collections across the 100 years (Milojevic \& Cox 2017); and a revised edition of the timeline on women in New Zealand architecture, prepared by Architecture + Women New Zealand (2017 [2013]). The latter newly named the women who had studied architecture in the School from the 1920s to the 1970s, when the institution started to become less particular about identifying women as such in its lists of student names.

This historic reflection followed survey texts on the history of architectural education in the United Kingdom (Crinson \& Lubbock 1994) and the United States (Ockman \& Williamson 2012). There is also a tradition of individual schools marking significant anniversaries with their own histories. Of these, the Architectural Association School of Architecture (AA) in London has been among the most prolific (Summerson 1947; Gowan 1973-75, 1975), while the Yale School of Architecture in New Haven, Connecticut, has produced perhaps the most exhaustive study of its own past (Stern \& Stamp 2016). The School of Architecture at the University of Liverpool is one that has attracted the attention of multiple authors, particularly developments that occurred under Charles Reilly's leadership (Crouch 2002; Dunne \& Richmond 2008; Richmond 2001; Sharples, Powers, \& Shippbottom 1996). 
In Australasia, the University of New South Wales celebrated 60 years of architecture in 2015 (Murray 2015), the University of Western Australia, 50 years of architecture in 2015 (George 2015), and Victoria University of Wellington, 40 years of architecture in 2016. The School of Architecture, Design and Planning at the University of Sydney celebrates its architecture centenary in 2018, while in 2019, the Faculty of Architecture, Building and Planning at the University of Melbourne celebrates both the centenary of that University's Architecture Atelier and the sesquicentenary of its teaching of architecture. The older planning programmes-those originally focused on town planning-were often established in schools or faculties of architecture, while more recent planning programmes have more diverse beginnings.

In addition to the centennial history and four exhibitions, the Auckland School of Architecture and Planning celebrated its centenary with a gala dinner enjoyed by 280 people, a series of panel discussions with alumni, and a symposium titled "Educating Architects and Planners, 1917-2017". This special issue of Interstices brings together seven of the 30 papers presented at the symposium.

The original call for papers for the symposium established our interests in a broad range of themes, including the formation and early history of schools and programmes, the gradual demise of the pupillage model, the extent to which Beaux-Arts methods were or were not used in particular schools, and more generally, the reliance on overseas models. Auckland's inaugural Professor of Architecture, for example, Cyril Knight, had trained at the University of Liverpool School of Architecture and worked in New York, and his background influenced the early direction of the School. British qualifications remained common among the Auckland staff until the 1950s, when greater diversity started to be seen, including the School's first European émigré staff. The early reliance on Britain extended to the professions, with ties to the Royal Institute of British Architects (RIBA) and the Town Planning Institute of London (TPI). This changed over time, as the New Zealand professions and the tertiary sector both matured. Thus, the modernisation and professionalisation of programmes were of interest to us. For most of the twentieth century, the New Zealand Institute of Architects (NZIA) was heavily involved in decisions about the opening of new architecture programmes in particular tertiary institutions; now it is hands-off, taking the view that whether or not a particular institution offers architecture is purely a business decision for that institution. Schools have also had changing priorities, and have responded to changing technologies, from environmental sustainability to the digital age, as well as changing demographics, including gender, ethnicity, and internationalisation. Key members of staff were another obvious theme, with their visions and their public voices, as critics or commentators. The work on our own centennial history had established further specific interests in accommodation, space, and the ways in which physical environments have influenced pedagogies at particular points in time.

While the symposium attracted a broad range of papers from across the region, the seven articles presented in this volume are tightly connected, and indeed interconnected, by virtue of their consistent focus on aspects of New Zealand architecture and planning education. As the Auckland School was New Zealand's only professional school of architecture until the mid-1970s, and also offered the country's first professional planning programme, this necessarily includes repeated reference to it and its history. 
In the first article, "Persisting Beaux-Arts Practices in Architectural Education", Milica Mađanovic investigates the endurance of Beaux-Arts practices in the Auckland School of Architecture from 1927 to 1969. She focuses on the School's teaching of the history and theory of architecture, and more specifically on the books it recommended as reading for the history and theory courses. Her start date follows not the School's opening, but rather the publication of reading lists in its annual prospectuses, and their inclusion of conservative, historicist texts that supported Beaux-Arts emphases on classicism, composition, and unity. Her conclusion is that "The reading lists published between 1927 and 1969 documented three phases of the Beaux-Arts influence on history and theory teaching at the Auckland School: predominance, from 1927 to 1947; transition, from 1948 to 1958; and then decline, from 1958 to 1969."

The second article is by Ann McEwan, who is already the author of one of the key texts on the history of architectural education in New Zealand, "Learning by Example" (1999). Here, in "Learning in London", she focuses on the New Zealanders who studied architecture at the Architectural Association School of Architecture (AA) in London. This included the likes of Samuel Hurst Seager and Frederick de Jersey Clere in the nineteenth century, and a much larger number in the first few decades of the twentieth century. Her study is informed by archival research in London, complemented by extensive newspaper searches. She shows that most of the New Zealanders who studied at the AA in the early twentieth century returned to New Zealand and practised here, with a considerable proportion becoming well known. She compares their experiences to those of the New Zealand painters and writers who spent time abroad, and concludes that the AA training would have enhanced the standing of those architects who returned.

With his article "Ernst Plischke as Teacher", Christoph Schnoor moves the volume to modernism and, more specifically, to the teaching initiatives of the Austrian-born émigré architect, Ernst Plischke (1903-1992). Plischke gave public lectures in Wellington in the 1940s and applied for the position of Professor of Design at the Auckland School of Architecture in 1947. He was unsuccessful in this application, but 16 years later, in 1963, took up a professorial position in design at the Academy of Fine Arts in Vienna, and taught there for 10 years. While the Auckland School in 1947 sought a professor with academic experience, Vienna in 1963 privileged practice experience and design reputation. Thus, Schnoor asks the question of whether academic experience or practice experience is the more useful criterion for selecting and appointing professors of design. He argues that Plischke was more than just an ordinary teacher, expecting his students to produce high-quality work and developing in them a "moral compass" and, he hoped, a "noble mind".

In 'Imric Porsolt: The 'Messenger of Modernism' in Exile”, Linda Tyler focuses on another émigré architect-academic, Hungarian Imric Porsolt (1909-2005). She surveys his career, including his training and early work in Prague, and his move to New Zealand in 1939, at the age of 30. Porsolt worked as an architect in Auckland during and after the war, started teaching part-time in the Auckland School of Architecture in the late 1940s, and then worked full-time in the School from 1950 through to his retirement in 1974 . He was important in broadening the scope of the history and theory teaching in the School, newly introducing modernism, the applied arts, and New Zealand architecture. He was also active as a writer on New Zealand art and architecture. Tyler shows that his personal 
approach derived from German philosophy and aesthetics, rondo-cubist Czech architecture, and the Viennese school of art history and criticism. He had a mission to educate others about modernism, evidenced by his instruction for the words "A Messenger of Modernism" to be engraved on his headstone.

In "Mud on His Boots", Robert Freestone focuses on the career and teaching initiatives of a third individual-Professor Robert Terence Kennedy (1903-1997), the University of Auckland's first Professor of Town Planning, appointed in 1957 to set up the Department of Town Planning within the Faculty of Architecture, and running it until his retirement in 1969. Kennedy had no formal qualifications, but a wealth of practice experience from the United Kingdom. Freestone's research reveals Kennedy's insecurities as an academic, but also the high regard in which others held him; clearly he saw himself quite differently from how others saw him. Freestone argues that Kennedy was "an archetypal British expatriate architect-planner, somewhat patrician but principled, steeped in old-world planning but not dogma, and striving to adapt best practice to the New Zealand environment." He concludes that the expatriate Briton established a "firm footing" for New Zealand's first professional qualification in town planning.

The starting point for Gill Matthewson's article, “Where Do You Go To?”, was her own experience as a first-year student at the Auckland School of Architecture in 1976. She was one of 24 women in a class of 74 students. Gender statistics in the School had shifted significantly that decade, following a dearth of women students throughout the 1950s and 1960s. Second-wave feminism gave women the confidence to imagine and pursue careers in the professions once again. Matthewson analyses the gender statistics from her own cohort, from pass and fail rates through to graduation and registration. She also explores the lives and careers of as many of her former classmates as she was able to track, providing a fine-grained reading of one particular student cohort from the School's history. She argues that the statistics and the stories demonstrate "the difficulty of architecture, both as a field of study and as a career"-for men, and especially for women-and shows that many alumni find rewarding work in architecture's "expanded field".

The final refereed article in this issue, "Propagating a Legacy", by Aaron Paterson and Michael Davis, is concerned with the Auckland School of Architecture's reputation, earned in the 1980s, as a "drawing school", with a recognised strength in "teaching and producing architectural media that challenges normative representations of the discipline". The pair have both taught second-year media in the School in recent years, including form-making and fabrication software such as Revit and Building Information Modelling (BIM). Their fear is that such programmes can encourage the production of work that is descriptive rather than speculative or critical; their aim is to teach the software in such ways as to maintain the School's critical drawing culture. They describe their response to this challenge, through encouraging "undisciplined drawings" and insisting that BIM can be considered "part of a design workflow that informs an idiosyncratic media practice, rather than an end in itself."

It is a pleasure to be presenting Lucy Vete's Master of Architecture (Professional) thesis project in this issue, titled "Shifting Grounds" and completed in the Auckland School of Architecture and Planning in 2017 under Jeremy Treadwell's supervision. With this project, Vete earned the top prize in the 2017 NZIA Student 
Design Awards. In this annual competition, each of New Zealand's three schools of architecture is represented by four finalists, and a jury selects a winner and two highly commendeds. Vete's thesis abstract describes her research on Tongan conceptions of home and homeland.

The issue's non-refereed section combines photographs from the Auckland School of Architecture and Planning's 2017 centenary celebrations; a review, by Sam Kebbell, of a recent exhibition of work by Sarosh Mulla and Aaron Paterson, titled Penumbral Reflections; and a photographic essay by Patrick Reynolds, recording the University of Auckland's Conference Centre Building, ahead of its likely demolition in 2019 or 2020.

This issue of Interstices is a counterpart to the School's 2017 centennial history publication. It is our conclusion that the researching and writing of histories of architectural and planning education is a worthwhile endeavour, because so many practitioners remember their education and training very vividly; it is formative, and influences careers and both personal and professional networks for many years afterwards. 
REFERENCES

Architecture + Women New Zealand, curators. (2017 [2013]). 100 years of architecture by women. Auckland: School of Architecture and Planning, University of Auckland, September 8, 2017-July 24, 2018.

Crinson, M., \& Lubbock, J. (1994). Architecture: Art or profession? Three hundred years of architectural education in Britain. Manchester and New York: Manchester University Press.

Crouch, C. (2002). Design culture in Liverpool 1880-1914: The origins of the Liverpoo/ School of Architecture. Liverpool: Liverpool University Press.

Dunne, J., \& Richmond, P. (2008). The world in one school: The history and influence of the Liverpool School of Architecture, 1894-2008. Liverpool: Liverpool University Press.

Gatley, J., \& Treep, L. (Eds). (2017). The Auckland School: 100 years of architecture and planning. Auckland: School of Architecture and Planning, University of Auckland.

George, B. (Ed.). (2015). UWA architecture: The first 50 years, 1965-2015. Perth: Cullity Gallery and the Faculty of Architecture, Landscape and Visual Arts.

Gowan, J. (1973-75). Projects, Architectural Association, 1946-71. London: Architectural Association.

Gowan, J. (Ed.). (1975). A continuing experiment: Learning and teaching at the Architectural Association, 1946-71. London: Architectural Association.

Manfredini, M., \& Rieger, U. curators. (2017). Design studio in action. Auckland: School of Architecture and Planning, University of Auckland, September 8-13.

McEwan, A. (1999). Learning by example: Architectural education in New Zealand before 1940. Fabrications: The Journal of the Society of Architectural Historians, Australia and New Zealand, 9, May, 1-16.

Milojevic, M., \& Cox, S., curators. (2017). 100 years, 100 books. Auckland: Architecture and
Planning Library, University of Auckland, March-December.

Milojevic, M., Treep, L., Barrie, A., \& Gatley, J., curators. (2017). The Auckland school: 100 years of architecture and planning. Auckland: Gus Fisher Gallery, September 8-November 4.

Murray, A., curator. (2015). Architecture by hand and mind: 60 years of architecture at UNSW. Sydney: Red Centre West Wing, University of New South Wales, 19-25 October.

Ockman, J., \& Williamson, R. (2012). Architecture school: Three centuries of educating architects in North America. Cambridge, Mass: MIT Press.

Richmond, P. (2001). Marketing modernisms: The architecture and influence of Charles Reilly. Liverpool: Liverpool University Press.

Sharples, J., Powers, A., \& Shippbottom, M. (1996). Charles Reilly and the Liverpool School of Architecture [Exhibition catalogue]. Liverpool: Liverpool University Press.

Stern, R., \& Stamp, J. (2016). Pedagogy and place: 100 years of architectural education at Yale. New Haven, CT: Yale University Press.

Summerson, J. (1947). The Architectural Association, 1847-1947. London: Architectural Association. 